\title{
ANALISIS LEGAL KERUGIAN KEUANGAN NEGARA PADA KONTRAK KONSTRUKSI
}

Oleh:

Vesmin Jani

\begin{abstract}
Abstrak
Kaitan dengan masalah keuangan negara dan sejarah perkembangan jasa konstruksi masa silam, banyak ketimpanganketimpangan, sehingga hal semacam itu menjadi refecensi bagi pemerintah untuk memperbaik kinerja dalam pengawasan, keuangan negara. Dilain pihak juga terjadi ulur tarik tersebut mungkin, pihak pemerintah juga menjalankan amanat undangundang yang memberikan wewenang kepadanya untuk menjalankan tugasnya. Artikel ini akan mengulas tentang keuangan negara dan kontrak konstruksi yang diurai dalam bentuk deskripsi.
\end{abstract}

Kata Kunci: Kerugian Keuangan Negara; Kontrak Kontruksi

\section{A. Pendahuluan}

Undang-Undang Jasa konstruksi Nomor 18 Tahun 1999 tentang Jasa Konstruksi dalam Pasal 41 sampai dengan Pasal 43 selain mengatur tentang sanksi administrasi juga mengatur tentang sanksi pidana terhadap penyimpangan pelaksanaan pekerjaan konstruksi. Ketentuan pidana dalam pasal 43 inilah yang kemudian oleh sebagian kalangan dipandang mengkriminalisasikan kontrak kerja konstruksi, sehingga menimbulkan polimik terhadap keberadaan pasal 43 tersebut. Pencantuman ketentuan pidana dalam UU No. 18 ahun 1999 tersebut, dipandang oleh pihak tertentu bertentangan dengan Pasal 11 international convenant on civil and political right (ICCPR), yang menyatakan bahwa No one shall be imprisoned merely on the ground of inability to fulfil a contractual obligation, yang memberi penghargaan atas kesucian berkontrak (the sanctity of contract) karena dibuat berdasarkan persetujuan bebas para pihak yang sah dan dihargai itu adalah kebebasan itu sendiri, sehingga Negara dipaksa untuk memberikan ruang kepada pengaturan private yang dibuat melalui kontrak oleh para pihak sebagaimana asas universal tentang kebebasan berkontrak.

Pada beberapa tahun belakangan, ramai diberitakan seputar temuan BPK dalam pekerjaan konstruksi yang berujung para penyedia jasa pelaksana konstruksi mesti mengembalikan sebagian untuk kontrak, lantaran dinilai merugikan Negara. Oleh ketua itu, Gapensi Jateng Drs. H. Djoko OryXahadi (Koran Suara Merdeka yang telah dimuat dalam situs www.merdeka.com pada tanggal 4 maret 2010) yang menyatakan bahwa jasa konstruksi sebenarnya punya UU No. 18 Tahun 1999, tentang Jasa 
Konstruksi dan PP No. 28 Tahun 2000, yang dirubah menjadi PP 04/2010 tentang Usaha dan peran Masyarakat Jasa Konstruksi, PP No. 29 Tahun 2000 tentang penyelenggaraan Jasa Konstruki, dan PP No. 30/2000 tentang Penyelenggaraan pembinaan Jasa konstruksi.

Lebih lanjut, ia menyatakan bahwa melalui UU dan PP tersebut sudah diatur dengan rinci hak dan kewajiban termasuk sanksi-sanksinya. Namun aparat hukum sering tidak menjadikan UU dan PP tersebut sebagai acuan hukum dalam menyelesaikan masalah, jika dipandang melanggar.

\section{B. Rumusan Masalah}

Berdasarkan uraian pada bagian pendahuluan sebelumnya, maka adapun rumusan masalah dalam artikel ini yaitu bagaimana analisis legal kerugian keuangan negara pada kontrak konstruksi?

\section{Pembahasan}

Tulisan ini akan mengulas tentang keuangan negara dan kontrak konstruksi yang diurai dalam bentuk deskripsi.

1. Keuangan Negara

Sebagaimana dijelaskan di atas bahwa, kontrak Jasa konstruksi adalah merupakan domain/wilayah hukum private, namun karena adanya unsure pemerintah, maka setiap kerugian yang muncul itu adalah merupakan keuangan negara, jika pengguna Jasa tersebut adalah pemerintah. Yang dimaksud dengan keuangan negara sebagaimana tertuang dalam Pasal 2 UU Nomor 17 Tahun 2003 yaitu:

a. Hak Negara untuk memungut pajak, mengeluarkan dan mengedarkan uang dan melakukan pinjaman;

b. Kewajiban Negara untuk menyelenggarakan tugas layanan umum pemerintahan Negara dan membayar tagihan pihak ketiga;

c. Penerimaan Negara;

d. Pengeluaran Negara;

e. Penerimaan Daerah;

f. Pengeluaran Daerah;

g. Kekayaan Negara/kekayaan daerah yang dikelola sendiri atau oleh pihak lain berupa uang, surat berharga, piutang,barang, serta hak-hak lain yang dapat dinilai dengan uang termasuk kekayaan yang dipisahkan pada perusahaan Negara/perusahaan Daerah. 
h. Kekayaan pihak lain yang di kuasai oleh pemerintah dalam rangka penyelenggaraan tugas pemerintahan dan/atau kepentingan umum; dan

i. Kekayaan pihak lain yang diperoleh dengan menggunakan fasilitas yang diberikan pemerintah.

Sementara dalam memori penjelasan Undang-Undang tersebut,pendekatan yang digunakan untuk menjelaskan pengertian dan ruang lingkup keuangan Negara adalah dapat dirumuskan dari sisi obyek, subyek, proses dan tujuan.

1) Dari sisi obyek

Yang dimaksud dengan keuangan Negara meliputi semua hak dan kewajiban yang dapat dinilai dengan uang, termasuk kebijakan dan kegiatan dalam bidang fiscal, moneter dan pengelolaan kekayaan Negara yang dipisahkan, serta segala sesuatu baik berupa uang, maupun berupa barang yang dapat dijadikan milik Negara berhubungan dengan pelaksanaan hak dan kewajiban tersebut.

2) Dari Sisi Subyek

Yang dimaksud dengan keuangan Negara meliputi, seluruh obyek sebagaimana tersebut di atas yang dimiliki Negara dan/atau dikuasai oleh pemerintah pusat,pemerintah Daerah, Perusahaan Negara/daerah, dan badan lain yang ada kaitannya dengan keuangan Negara.

3) Dari Sisi Proses

Yang dimaksud dengan keuangan Negara adalah, mencakup seluruh rangkaian kegiatan yang berkaitan dengan pengelolaan obyek sebagaimana tersebut di atas mulai dari perumusan kebijakan dan pengambilan keputusan sampai dengan pertanggungjawabannya.

4) Dari Sisi Tujuan

Keuangan Negara meliputi seluruh kebijakan, kegiatan dan hubungan hukum yang berkaitan dengan pemilihan dan/atau penguasaan obyek sebagaimana tersebut di atas dalam rangka penyelenggaraan pemerintahan Negara.

Oleh karena itu, dengan ruang lingkup yang begitu luas, maka tentunya pemerintah selalu melakukan pengawasan dengan ekstra hati-hati, agar tidak dapat terjerumus lagi seperti pada masa orde baru. 


\section{Kontrak Konstruksi}

Dalam ilmu hukum, hubungan kontraktual merupakan hubungan hukum dalam bidang keperdataan atau bersifat private sehingga berada dalam ruang lingkup hukum privat. Sebagaimana berikut ini:

a. Kontrak kerja kontruksi adalah keseluruhan dokumen yang merupakan hubungan hukum antara pengguna jasa dan penyedia jasa dalam penyelenggaraan pekerjaan konstruki;

b. Kegagalan bangunan adalah keadaan bangunan, yang setelah diserahterimakan oleh penyedia jasa kepada pengguna jasa, menjadi tidak berfungsi baik secara keseluruhan maupun sebagian dan/atau tidak sesuai dengan ketentuan yang tercantum dalam kontrak kerja konstruksi atau pemanfaatannya yang menyimpang sebagai akibat kesalahan penyedia jasa dan/atau pengguna jasa;

c. Kontrak konstruksi seharusnya berada di ranah hukum privat;

d. UU. No. 18/1999, mengatur tegas sanksi-sanksi atas pelanggaran Undang-Undang jasa konstruksi;

e. Sanksi dapat berupa sanksi administrative maupun sanksi pidana;

f. Selain itu dimungkinkan penyelesaian sengketa antara pengguna Jasa dengan penyedia Jasa melalui lembaga mediasi;

g. Persoalan timbul jika pihak pengguna Jasa konstruksi adalah pemerintah;

h. Selain tunduk pada Undang-Undang Jasa konstruksi, masih harus mengikuti ketentuan yang berkaitan dengan proyek pemerintah, seperti kepres No. 80 Tahun 2003.

i. Namun demikian, karena adanya unsur pemerintah, maka setiap timbul kerugian penegak hukum selalu menggunakan pendekatan hukum public, seperti UU Tipikor, UU Keuangan Negara, UU perbendaharaan negara;

j. Akibat setia wanprestasi bias masuk dalam ranah kerugian Negara yang bias di jerat dengan Undang-Undang tindak Pidana korupsi.

Menurut aturan yang telah dimuat dalam Pasal 14 UU No. 31 Tahun 1999 dinyatakan bahwa setiap orang yang melanggar ketentuan Undang-Undang yang secara tegas menyatakan bahwa pelanggaran terhadap ketentuan Undang-Undang tersebut sebagai tindak pidana korupsi berlaku ketentuan yang diatur dalam Undang-undang ini. Hal ini secara otentik dapat diartikan bahwa UU No. 18 Tahun 1999 tentang Jasa Konstruksi, harus memuat secara tegas tentang tuntutan tindak pidana korupsi, bila mana terjadi pelanggaran terthadap Undang-Undang Jasa konstruksi tersebut. Fakta 
yuridisnya adalah di dalam UU No. 18 Tahun 1999 tentang Jasa Konstruksi, tidak terdapat satu pasalpun yang menguraikan mengenai tuntutan pidana korupsi, sebagaimana dipersyaratkan dalam pasal 14 UU No. 31 Tahun 1999.

Akan tetapi perlu diperhatikan secara lebih jauh bahwa alasan lain mengapa UU No. 31 Tahun 1999 jo UU No. 22 Tahun 2001 tidak dapat dikenakan pada pengaturan tindak pidana dalam Jasa Konstruksi:

a. Bahwa UU No. 31 Tahun 1999 telah disahkan dan berlaku efektif pada tanggal 16 Agustus 1999, sementara UU No. 18 Tahun 1999 telah dan berlaku efektif pada tanggal 7 Mei 1999. Hal ini berarti bahwa undang-undang jasa konstruksi telah terlebih dahulu berlaku dan tidak ada ketentuan peralihan yang menyatakan bahwa undang-undang yang dibentuk sebelum UU No. 31 Tahun 1999 dapat dikenakan tuntutan tindak pidana dalam Jasa Konstruksi.

b. Bahwa dalam UU No. 18 Tahun 1999, tehadap perbuatan hukum yang melanggar ketentuan di dalam peraturan perundangan tersebut hanya di nyatakan dapat diajukan gugatan dan tuntutan pidana umum, bukan bukan tindak pidana korupsi. Pasal 14 UU No.31 Tahun 1999 jo UU No. 20 Tahun 2001 tersebut dapata dijelaskan empat hal yang dapat dikemukakan, sebagai landasan bahwa pasal ini tidak dapat diberlakukan pada UU No. 18 Tahun 1999 antara lain:

1) Dengan adanya ketentuan yang terdapat dalam pasal tersebut, apa yang dimaksud dengan tindakan pidana korupsi, kecuali yang sudah terdapat pada pasal-pasal 2, 3, 5, 7, 8, 9, 10, 11, $12,12 \mathrm{~B}$ dan 13, juga termasuk ketentuan yang terdapat di dalam undang-undang lainnya, tetapi dengan syarat bahwa di dalam undang-undang lain tersebut terdapat ketentuan yang menyataakan scara tegas bahwa pelanggaran yang terdapat di dalam undang-undang lain tersebut merupakan tindak pidana korupsi;

2) Dapat menafsirkan, maksud dari pasal 14 tersebut tidak hanya dapat dituangkan dalam peraturan perundang-undangan, yang berbentuk peraturan pemerintah pengganti UndangUndang mempunyai hirarki setingkat;

3) Penjelasan pasal 14 memuat bahwa yang dimaksud dengan ketentuan yang berlaku dalam Undang-Undang ini, dalam pasal 14, baik yang hukum pidana materiil maupun hukum pidana formil. Dengan demikian pasal 14 hendak menentukan jika dalam suatu undangundang terdapat ketentuan bahwa pelanggaran terhadap ketentuan yang terdapat dalam undang-undang tersebut dinyatakan sebagai tindak pidana korupsi, maka berlaku ketentuan- 
ketentuan, baik yang merupakan hukum pidana materiil maupun yang merupakan hukum formil, yang terdapat didalam UU No. 20 Tahun 2001 jo UU No. 30 Tahun 2002; dan

4) Sampai sekarang undang-undang yang dimaksud oleh pasal 14 tersebut belum ada yang mengaturnya secara tegas.

\section{Kesimpulan dan Saran}

Berdasarkan uraian pada bagian pembahasan sebelumnya, maka dapat ditarik bahwa pada prinsip kontrak jasa konstruksi sudah mempunyai, aturan-aturan tersendiri yang cukup dipergunakan untuk menyelesaikan masalah jika ada pelanggaran. Namun perlu di garis bawahi, bahwa kaitan dengan masalah keuangan negara dan sejarah perkembangan jasa konstruksi masa silam, banyak ketimpanganketimpangan, sehingga hal semacam itu menjadi refecensi bagi pemerintah untuk memperbaik kinerja dalam pengawasan, keuangan negara. Dilain pihak juga terjadi ulur tarik tersebut mungkin, pihak pemerintah juga menjalankan amanat undang-undang yang memberikan wewenang kepadanya untuk menjalankan tugasnya.

Agar dapat menespon cara pandang yang betbeda antara akadimisi dan para pakar di luar Sistem pemerintah yang ada, perlu menyatuhkan presepsi melalui mekanisme atau cannal yang tersedia, agar bisa memberikan kepastian hukum kepada pihak yang sebagai korban pada undang-undang tersebut.

\section{DAFTAR PUSTAKA}

Nindyo Pramono, 2010, Kriminalisasi Vs Kesucian Kontrak, Seminar Nasional Kontrak Kerja Jasa Konstruksi.

Andrian Sutady,2008, Aspek Hukum Pengadaan Barang dan Jasa, dan berbagai permasalahannya, Jakarta: Sinar Grafika.

Telaumbanua, Dalinama. 2019. “Kumpulan Undang-undang KPK Dalam Satu Naskah.” LawArXiv. November 29. doi:10.31228/osf.io/ysju2.

Philipus M. Hadjon, 2010, Kontrak dengan Pemerintah ditinjau dari Sudut Pandang Hukum Asministrasi,Seminar Nasional Kontrak Kerja Jasa Konstruksi.

Telaumbanua, Dalinama. 2020. "Restriktif Status Dewan Pengawas KPK." Jurnal Education and Development. vol. 8, no. 1

Undang-Undang Nomor 18 Tahun 1999 tentang Jasa Konstruksi. 
Undang-Undang Nomor 17 Tahun 2003 tentang Keuangan Negara.

Undang-Undang Nomor 31 Tahun 1999 tentang Pemberantas Tindak Pidana Koruksi. 